\title{
Challenges in understanding Sjögren's syndrome - improved insights into the pathogenesis generate hope for innovative therapies?
}

\author{
Thomas Dörner* \\ See related reviews by Jacob and Stohl, http://arthritis-research.com/content/13/4/228; Shao and Cohen, http://arthritis-research.com/ \\ content/13/1/202; Holle et al., http://arthritis-research.com/content/13/3/224; Sipsas et al., http://arthritis-research.com/content/13/2/212; \\ Vitali, http://arthritis-research.com/content/13/4/233; Low and Witte, http://arthritis-research.com/content/13/3/218; Youinou and Pers, \\ http://arthritis-research.com/content/13/4/227; Delaleu et al., http://arthritis-research.com/content/13/3/217; and Kallenberg et al., \\ http://arthritis-research.com/content/13/1/205.
}

\begin{abstract}
The reviews in this series on Sjögren syndrome provide an up-to-date summary and perspectives on the pathogenesis of this interesting entity with glandular and frequently systemic manifestations, the value of preclinical models, and our current understanding of therapeutic approaches. The last of these includes what has been learned from trials blocking tumor necrosis factor and, more recently, anti-CD20 therapy. Potential therapeutic targets, such as blockade of the B cell-activating factor, the role of interferon-alpha, and targeting CD22, are discussed.
\end{abstract}

This series on Sjögren syndrome, like disease-oriented review series on systemic lupus erythematosus (SLE) $[1,2]$, vasculitides, and comorbidities of rheumatic conditions [3], consists of articles that review recent topics, bring us up to date, and provide innovative views [4-8]. Respected researchers of rheumatology and clinical immunology with a great deal of experience in this particular systemic disease provide these overviews and share their perspectives. It is notable that the advent of innovative immune interventions in rheumatoid arthritis within the last decade and the recent approval of the antiB cell-activating factor/B lymphocyte stimulator (antiBAFF/BLyS) inhibitor belimumab for SLE have changed the lives of our patients and the treatment armamentarium, but there is ongoing research for better therapeutic targets in Sjögren syndrome.

*Correspondence: tdoerner@charite.de

CC12, Charite Universitätsmedizin Berlin, Chariteplatz 01, 10098 Berlin, Germany

Biomed Central o 2011 Biomed Central Ltd
With this in mind, the authors of these reviews address central questions about the immunopathogenesis of Sjögren syndrome. Sipsas and colleagues [4] explore the potential role of retroviruses in initiating or maintaining disease. Vitali [5] examines the differences and similarities of sicca symptoms and risk of developing lymphoma between patients with HIV or hepatitis $C$ virus infection and those with Sjögren syndrome. Low and Witte [6] investigate the central role of type I interferons (IFNs) driving innate immunity. Youinou and Pers [7] address the obvious abnormalities of other cytokines such as BAFF/BLyS, interleukin-17, and tumor necrosis factoralpha (TNF- $\alpha$ ) in the context of the local production in the inflamed salivary tissues.

While further insight into the pathogenesis of Sjögren syndrome in humans is of critical relevance to arrive at newer therapies, various preclinical models of either spontaneous or inducible Sjögren-like disease, as comprehensively reviewed by Delaleu and colleagues [8], are important for testing candidate therapeutics. In this context, the advantages and disadvantages of the different mice strains remind us of the different models of arthritis [9] and lupus [10]. While these aspects can be discussed at length, there is a possibility that even patients with Sjögren can represent such heterogeneity. Moreover, Kallenberg and colleagues [11] summarize the current data from various trials studying inhibition of TNF- $\alpha$, IFN- $\alpha$, BAFF, and anti-CD20 and -CD22 therapy and put this in the context of what these trials have to say about the immune abnormalities in Sjögren syndrome. With the continuous initiatives of identifying patients' profiles and responses [12], the information summarized in this review series could reflect the current understanding of the (immuno)pathogenesis of Sjögren syndrome and the therapeutic possibilities and limitations, which all may support our continuous search for improved therapies for this interdisciplinary disease. 


\section{Autoimmune Basis of Rheumatic Diseases}

This article is part of a series on Sjögren's syndrome, edited by Thomas Dörner, which can be found online at http://arthritis-research.com/series/Sjögrens

This series forms part of a special collection of reviews covering major autoimmune rheumatic diseases, available at:

http://arthritis-research.com/series/abrd

\section{Abbreviations}

BAFF/BLyS, B cell-activating factor/B lymphocyte stimulator; IFN, interferon; SLE, systemic lupus erythematosus; TNF-a, tumor necrosis factor-alpha.

\section{Competing interests}

The author declares that he has no competing interests.

\section{Published: 19 August 2011}

\section{References}

1. Jacob N, Stohl W: Cytokine disturbances in systemic lupus erythematosus. Arthritis Res Ther 2011, 13:228.

2. Shao WH, Cohen PL: Disturbances of apoptotic cell clearance in systemic lupus erythematosus. Arthritis Res Ther 2011, 13:202.

3. Holle JU, Moosig F, Dalhoff K, Gross WL: Conditions in subjects with rheumatic diseases: pulmonary manifestations of vasculitides. Arthritis Res Ther 2011, 13:224

4. Sipsas NV, Gamaletsou MN, Moutsopoulos HM: Is Sjögren's syndrome a retroviral disease? Arthritis Res Ther 2011, 13:212.
5. Vitali C: Immunopathologic differences of Sjögren's syndrome versus sicca syndrome in HCV and HIV infection. Arthritis Res Ther 2011, 13:233.

6. Low H, Witte T: Aspects of innate immunity in Sjögren's syndrome. Arthritis Res Ther 2011, 13:218.

7. Youinou P, Pers JO: Disturbance of cytokine networks in Sjögren's syndrome. Arthritis Res Ther 2011, 13:227.

8. Delaleu N, Nguyen CQ, Peck AB, Jonsson R: Sjögren's syndrome: studying the disease in mice. Arthritis Res Ther 2011, 13:217.

9. Ho PP, Lee LY, Zhao X, Tomooka BH, Paniagua RT, Sharpe O, BenBarak MJ, Chandra PE, Hueber W, Steinman L, Robinson WH: Autoimmunity against fibrinogen mediates inflammatory arthritis in mice. J Immuno/ 2010 184:379-390.

10. Diamond B, Bloom O, Al Abed Y, Kowal C, Huerta PT, Volpe BT: Moving towards a cure: blocking pathogenic antibodies in systemic lupus erythematosus. J Intern Med 2011, 269:36-44.

11. Kallenberg CGM, Vissink A, Kroese FGM, Abdulahad WH, Bootsma H: What have we learned from clinical trials in primary Sjögren's syndrome about pathogenesis? Arthritis Res Ther 2011, 13:205

12. Seror R, Ravaud P, Mariette X, Bootsma H, Theander E, Hansen A, RamosCasals M, Dörner T, Bombardieri S, Hachulla E, Brun JG, Kruize AA, Praprotnik S, Tomsic M, Gottenberg JE, Devauchelle V, Devita S, Vollenweider C, Mandl T, Tzioufas A, Carsons S, Saraux A, Sutcliffe N, Vitali C, Bowman SJ; EULAR Sjögren's Task Force: EULAR Sjogren's Syndrome Patient Reported Index (ESSPRI): development of a consensus patient index for primary Sjogren's syndrome. Ann Rheum Dis 2011, 70:968-972.

doi:10.1186/ar3425

Cite this article as: Dörner T: Challenges in understanding Sjögren's syndrome - improved insights into the pathogenesis generate hope for innovative therapies? Arthritis Research \& Therapy 2011, 13:123. 